\title{
Ventral abdominal hernia in a common cockatiel (Nymphicus hollandicus) - a case report
}

\author{
Marko Pećin ${ }^{1 *}$, and Željko Gottstein ${ }^{2}$ \\ ${ }^{I}$ Clinic for Surgery, Orthopaedics and Ophthalmology, Faculty of Veterinary Medicine, University of Zagreb, \\ Zagreb, Croatia \\ ${ }^{2}$ Institute of Poultry Diseases with Clinic, Faculty of Veterinary Medicine, University of Zagreb, Zagreb, \\ Croatia
}

\section{PEĆIN, M., Ž. GOTTSTEIN: Ventral abdominal hernia in a common cockatiel (Nymphicus hollandicus) - a case report. Vet. arhiv 89, 735-741, 2019.}

\section{ABSTRACT}

Not many abdominal hernias in small birds have been clearly described. As in other animals, ventral abdominal hernias have been characterized as a separation of the abdominal musculature on the ventral midline. Hernias are often related to breeding, egg binding or influenced by hormones. This article describes one case of abdominal hernia in a five year old female cockatiel. A painless, $3 \mathrm{~cm}$ in diameter and non-reducible mass was located in the ventral abdominal region. The mass was less than $1 \mathrm{~cm}$ from the cloaca. The bird had had problems with defecation for several months. After clinical examination and contrast radiogram, an abdominal hernia was diagnosed. Surgical repair was performed under general anesthesia and herniorrhaphy was indicated. After skin incision, a large mass of yellowish fat tissue was discovered and the intestines within with adhesions. The hernial sack contents were resected using blunt cotton swabs soaked in saline. For repair of the abdominal hernial ring and the abdominal wall, a simple continuous suture pattern with polyglyconate 4-0 was used. The skin was also sutured with a simple continuous pattern. Normal defecation returned within hours post op. The follow up examination after one month revealed no complications and no recurrence of the hernia.

Key words: cockatiel; ventral hernia; surgical repair; cotton swab

\section{Introduction}

The etiology of abdominal hernias in birds is unknown (BENNET, 1994) and the reasons may be congenital or acquired, such as the weakening of the abdominal musculature caused by egg-laying (HARISSON and HARISSON, 1998) malnutrition or endocrine imbalances; hyperestrogenism. Other reasons include trauma, straining, egg binding and animal attacks. Occasionally herniation occurs secondary to abdominal

\footnotetext{
${ }^{*}$ Corresponding author:

Assist. Prof. Marko Pećin, PhD, DVM, Faculty of Veterinary Medicine, University of Zagreb, Heinzelova 55, 10000 Zagreb, Croatia, Phone: +385 12390 391; Fax: +385 12390 380; E-mail: mpecin@vef.hr
} 
lipoma, other neoplasia, or other space-occupying masses (MACWHIRTER, 2004). Due to hormonal imbalance and egg-laying, abdominal hernias occur more frequently in female bird species, mostly Psittacine. In the treatment of hernias, the surgical approach is often considered. Some authors consider dietary and weight loss changes as a nonsurgical solution (FORBES, 2002). Surgery of small birds because of their small body size and increased metabolic rate, involves major risks, and must be done with controlled conditions, equipment and knowledge of microsurgical techniques and bird anesthesia. Therefore, the patient's condition must be carefully assessed and the patient must be stabilized before surgery. Appropriate intraoperative and postoperative analgesia and body temperature must be controlled. This case report describes the surgical repair of a ventral abdominal hernia, not associated with trauma, in a female cockatiel.

\section{Materials and methods}

A five-year-old cockatiel, weighing 108 grams, was referred to the Surgery Clinic of the Faculty of Veterinary Medicine in Zagreb, Croatia, with a 2 month history of abdominal swelling and occasionally obstipation. The swelling became larger and larger over one month to almost $3 \mathrm{~cm}$ in diameter (Fig. 1). The owner presented radiographs with contrast showing a suspected ventral abdominal hernia, as shown in Fig. 2. On admission the cockatiel had a rectal temperature of $40^{\circ} \mathrm{C}$ with a pulse of more than 200 beats per minute. Its respiratory rate was 30 breaths per minute. The floor of the bird cage was full of normal colored excrement. On the ventral side of the abdomen, $1 \mathrm{~cm}$ from the cloaca, a painless, non-reducible yellowish mass, $3 \mathrm{~cm}$ in diameter, was noticed. The skin above was without feathers.

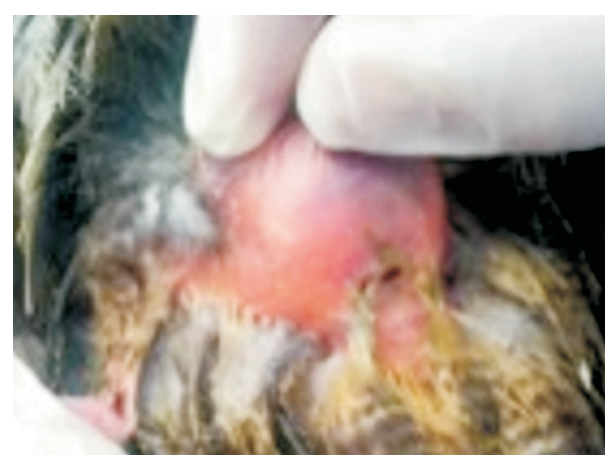

Fig. 1. The mass $3 \mathrm{~cm}$ in diameter ventral to the cloaca with featherless area 


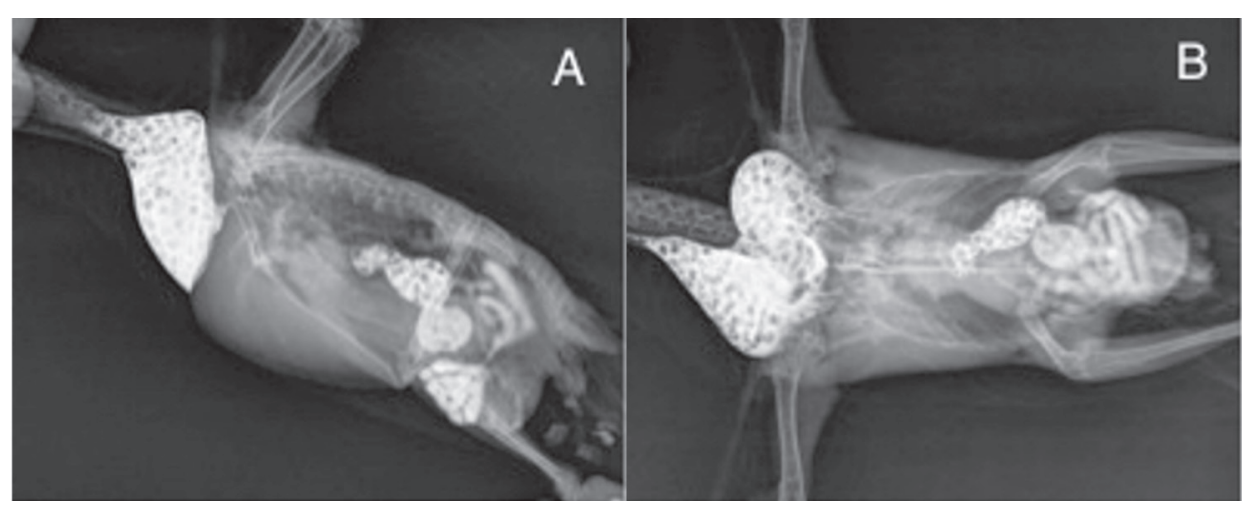

Fig. 2. The radiograms of profile $1 \mathrm{~A}$ and sagittal $1 \mathrm{~B}$ projections of the bird in toto showing the ventral abdominal hernia with contrast filled intestines in the hernia sac

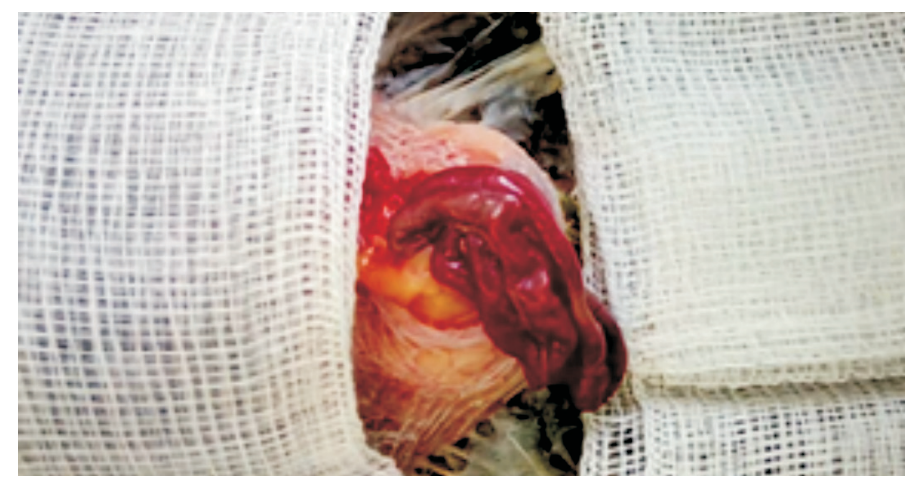

Fig. 3. The yellowish fat tissue mass with intestine adhesion in the hernia sac

The animal was clinically stable and herniorrhaphy under general anesthesia was suggested. Pre-surgical starvation was initiated only for the last one hour. The cockatiel was placed under general anesthesia using ketamine hydrochloride in a dosage of 30 $\mathrm{mg} / \mathrm{kg}$ and butorphanol in a dosage of $1 \mathrm{mg} / \mathrm{kg}$, applied to the pectoral muscle. General anesthesia was maintained with $2.5 \%$ sevoflurane and oxygen $2 \mathrm{~L}$ through a breathing mask. After feather removal and surgical field preparation, the cockatiel was placed in semi dorsal recumbency on a soft veterinary diaper with a heating pad underneath, with its head slightly raised to prevent aspiration. The wings were placed close to the body, while the legs were restrained by the assistant's hands and abducted in the caudal direction. A herniotomy was performed using blade No. 15 and micro scissors. It revealed a yellowish fat mass with intestine adhesion, and a small opening on the abdominal wall cranial to the cloaca (Fig. 3). The hernial contents were inspected and reduced using 
surgical swab sticks infused with saline (Fig. 4). It was not possible to reduce the hernia without making an additional $5 \mathrm{~mm}$ cut in the abdominal wall cranially to the existing opening. The incision was then extended with fine preparation scissors. After the hernia sack was opened and trimmed, the hernia was reduced and the opening was closed by a continuous suture using polyglyconate 4-0, as shown in Fig. 5. The subcutaneous tissue was sutured in the same fashion. The skin was also sutured in continuous pattern using the same suture material.

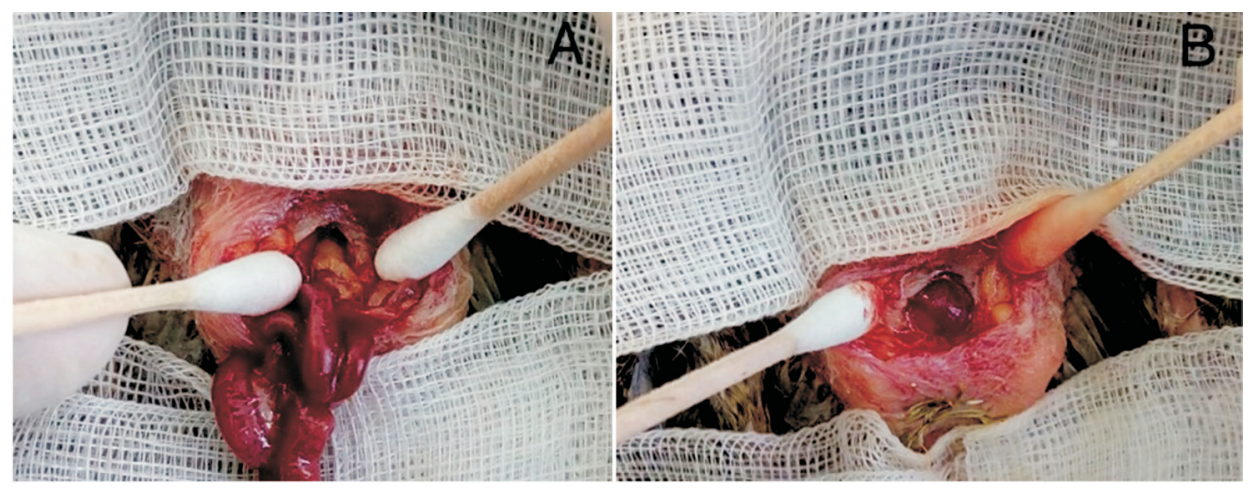

Fig. 4A. Inspection of the hernia sac with cotton swab sticks. Fig. 4B showing reduced hernia contents using cotton swab sticks with the abdominal wall defect presented.

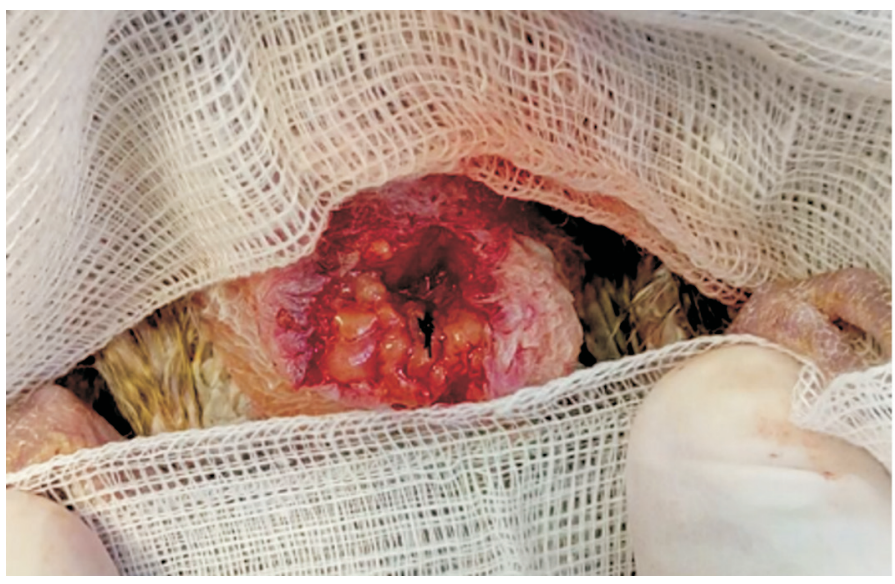

Fig. 5. Abdominal wall defect closure with polyglyconate 4-0 sutures

Postoperative management consisted of analgesia with meloxicam $0.5 \mathrm{mg} / \mathrm{kg}$ subcutaneously for 3 days. A heating pad was used until the cockatiel was on its feet. Cage 
resting was suggested and an improvised cardboard collar was placed to prevent suture removal. Antibiotic enrofloxacin $10 \%$ in a dosage of $10 \mathrm{mg} / \mathrm{kg}$ was administered orally for 7 days postoperatively. Normal defecation returned within few hours post operatively and the bird was on its feet one hour after surgery. The follow up examination after one month revealed no complications and no recurrence of the hernia. The skin sutures were removed by the owner to reduce stress 12 days after surgery.

\section{Discussion}

Not many abdominal hernias in small birds have been clearly described. As in other animals, ventral abdominal hernias have been characterized as the separation of the abdominal musculature on the ventral midline but have also been rejected as true hernias due to the absence of an opening in the aponeurosis of the abdominal muscles. Hernias are commonly seen in middle aged or older female birds. Obesity is a risk factor for abdominal hernia in female Psittacines, such as cockatoos (FORBES, 2002; MACWHIRTER, 2004) and is associated with high energy food that can lead to higher egg production. More egg production can lead to hormonal imbalance and hepatic lipidosis (LANGOLIS and JONES, 2001) that are risk factors for developing hernias. Mechanical stretching of abdominal wall due to egg laying can weaken the muscles and therefore cause wall rupture (HARRISON and HARRISON, 1998). Also breeding, abdominal tumors, trauma and formation of a urate concretion can cause abdominal hernias, as in cockatiels (MARTIN, 1986). In this case, the definitive etiology of hernia was unknown but it seems to have been caused by acquired factors such as inflammation due to eggbinding and obstipation, according to the owner. Age was not a primary factor. The bird was only five years old. Traumas in birds are very rare. Large tumors, hematomas or fatty tissue layers may occur in the distal abdominal area near the cloaca, therefore diagnosis of hernias should be confirmed by contrast radiographs (McMILAN, 1983) or ultrasound (COLES, 1997).

Common radiograph can be diagnostic for the loss of the abdominal wall integrity, egg binding or other associated bone traumas. Prompt surgical repair of the hernia is important if the bird has difficulty passing urates and feces, or has abdominal viscera within the hernial sack (MACWHIRTER, 2004), as in our case. Surgical repair was done because the bird was clinically stable and in good condition without any additional trauma, and a herniorrhaphy was indicated. Adhesions of the peritoneum and intestines with fatty tissue were found on the caudal part of the intestines due to the long period of time before the surgical procedure. Using sterile cotton swabs soaked in saline for tissue preparation proved to be minimally invasive and served as a fine blunt tool for visceral organ reposition and adhesion removal. Peritoneal adhesions may be classified as congenital or acquired, which in turn can be classified as post-inflammatory or postoperative, and 
can cause clinically important complications such as intestinal obstruction, pain, female infertility and difficulties at the time of additional operation (ELLIS, 1997). In our case adhesions were present due to the chronicity of the hernia. We used a monofilament suture polygliconate 4-0 for hernia ring closure to prevent further adhesions that may occur with braided suture material. In some cases braided material and thinner threads can be used if the defect in the abdominal wall is not large and the bird is small, or it can be sutured in two layers (JAHROMI et al., 2009). The skin was sutured using the same material. Usage of absorbable monofilament sutures is possible for skin closure in birds (SMOLEC et al., 2009).

The combination of ketamine and butorphanol proved to be a good induction option for a short surgical procedure, assisted by sevoflurane through a face mask. The bird was not intubated because of its size and the lack of a small diameter tracheal tube. Smaller birds, less than $100 \mathrm{~g}$, are generally not intubated because of the risk of blockage of tubes by respiratory secretions (FORBES, 2002). The surgical field must be aseptically prepared and disinfected with iodine to avoid alcohol evaporation, and therefore the additional heat loss of the bird. Feathers should be removed only near the surgical site for the same reasons, but enough to allow aseptic conditions (FORBES, 2002). In our case, povidoniodine was used with minimal feather removal. In anesthesia and surgical procedures, especially abdominal surgery, the bird's head must be raised in relation to the body by $30^{\circ}$ to prevent any fluid from entering the lung area. The surgical procedure must be quick, and post-surgical care also affects the outcome of the procedure and reduces unnecessary stress. Improvisational cardboard or an old radiograph may be used as a collar to prevent self-trauma, as in our case. Heating pads, analgesia, fluid and nutritional therapy should be considered in recovery (MACWHIRTER, 2004). In this case the cockatiel was in good condition, without malnutrition problems. Recovery was quick, within one hour post operatively, with the bird placed on a heating pad. Old ventral hernias in cockatiel can be surgically repaired and reconstructed using blunt separation of adhesions using saline soaked cotton swabs, and abdominal wall reconstruction using a continuous suture pattern with polyglyconate 4-0 (Maxon ${ }^{\mathrm{TM}}$, Medtronic Covidien, Switzerland).

\section{References}

BENNET, R. A. (1994): Soft tissue surgery. In: Avian Medicine: Principles and Application. (Ritchie, B. W., G. J. Harrison, L. R. Harisson, Eds.), Wingers Publishing, Florida, pp. 10971136.

COLES, B. H. (1997): Avian Medicine and Surgery. $2^{\text {nd }}$ ed. Blackwell Science Ltd, Oxford, p. 172.

ELLIS, H. (1997): The clinical significance of adhesions: focus on intestinal obstruction. Eur. J. Surg. Supp. 577, 5-9.

FORBES, N. A. (2002): Avian gastrointestinal surgery. Sem. Avi. Exot. Pet. Med. 11, 196-207.

DOI: 10.1053/saep.2002.126573 
M. Pećin and Ž. Gottstein: Surgical repair of hernia in bird

HARISSON, G. J., L. R. HARISSON (1998): Clinical Avian Medicine and Surgery. W.B. Saunders, Philadelphia, p. 225.

JAHROMI, A. R., S. D. NAZHVANI, S. HADDADI (2009): Ventral abdominal hernia in a common Myna (Acridotheres tristis). Vet. arhiv 79, 621-625.

LANGOLIS, I. M., P. JONES (2001): Ventral abdominal hernia associated with hepatic lipidosis in a Red Lory (Eos bornea). J. Avi. Med. Surg. 15, 216-222.

DOI: 10.1647/1082-6742(2001)015[0216:vahawh]2.0.co;2

MACWHIRTER, P. (2004): A rewiew of 60 cases of abdominal hernias in birds. In: Proceedings of the Annual Conference on Association Avian Veterinary. Nevada, pp. 27-37.

MARTIN, H. D. (1986): Abdominal hernia with formation of a urate concretion in a cockatiel. J. Am. Vet. Med. Assoc. 15, 1332-1333.

McMILAN, M. C. (1983): Avian gastrointestinal radiography. Compend. Contin. Educ. Vet. 5, 273-278.

SMOLEC, O., J. KOS, D. VNUK, T. BABIC, N. B. BOTTEGARO (2009): Abdominal ventral hernia in a pigeon (Columba livia): a case report. Vet. Med. 54, 291-294.

DOI: $10.17221 / 89 / 2009$-vetmed

Received: 11 March 2018

Accepted: 10 May 2019

\section{PEĆIN, M., Ž. GOTTSTEIN: Ventralna abdominalna hernija u nimfe (Nymphicus hollandicus) - prikaz slučaja. Vet. arhiv 89, 735-741, 2019. \\ SAŽETAK}

U danas dostupnoj literature nema puno prikaza slučajeva kila u malih ptica. Kao i u drugih životinja ventralne abdominalne kile opisane su kao razdvajanje mišićja trbušnog zida u središnjoj ventralnoj liniji. Kile u ptica su često povezane sa reprodukcijom, zaostalim jajetom ili hormonima. Ovaj članak prikazuje slučaj ventralne trbušne kile u pet godina stare nimfe. Bezbolna, $3 \mathrm{~cm}$ u promjeru, nereponibilna tvorba primjećena je na ventralnom dijelu trbuha. Tvorba je bila smještena manje od $1 \mathrm{~cm}$ od kloake. Nimfa je imala problema sa začepom nekoliko mjeseci. Nakon kliničkog pregleda i kontrastnog rendgenograma, dijagnosticirana je ventralna trbušna kila. Kirurško liječenje provedeno je u općoj anesteziji te je učinjena herniorafija. Nakon kožnog reza primjećena je velika žuta masa masnog tkiva te zavoji tankog crijeva sa priraslicama. Sadržaj hernijalne vreće je reseciran i prepariran tupo pomoću štapića s vatom natopljenih u fiziološku otopinu. Za šivanje i rekonstrukciju hernijalne vreće i trbušne stijenke korišten je produžni šav poliglikonatom 4-0. Koža je sašivena također produžnim šavom. Nekoliko sati poslije operacije ptica je dobila stolicu. Mjesec dana poslije operacije ptica nije pokazivala nikakve simptome povrata kile i obstipacije.

Ključne riječi: nimfa; ventralna kila; kirurško liječenje; vatirani štapići

Vet. arhiv 89 (5), 735-741, 2019 
